\title{
Mısır unu ilavesinin pandispanya tipi keklerin morfogeometrik, fonksiyonel ve tekstürel özelliklerine etkisi
}

\author{
The effect of corn flour addition on morphogeometric, functional and textural \\ properties of sponge type cakes
}

\author{
Mehmet KÖTEN ${ }^{1 *}$, Ahmet Sabri ÜNSAL ${ }^{2}$ iD \\ ${ }^{1}$ Kilis 7 Aralık Üniversitesi, Yusuf Şerefoğlu Sağlık Bilimleri Fakültesi, Beslenme ve Diyetetik Bölümü, Kilis, Türkiye \\ ${ }^{2}$ Harran Üniversitesi, Mühendislik Fakültesi, Gıda Mühendisliği Bölümü, Şanlıurfa, Türkiye \\ ${ }^{1}$ https://orcid.org/0000-0002-8232-8610; ${ }^{2}$ https://orcid.org/0000-0002-8012-3208
}

\section{To cite this article:}

Köten, M. \& Ünsal, A.S. (2021). Mısır unu ilavesinin pandispanya tipi keklerin morfogeometrik, fonksiyonel ve tekstürel özelliklerine etkisi. Harran Tarım ve Gıda Bilimleri Dergisi, 25(2): 172184.

DOI: $10.29050 /$ harranziraat.850654

\footnotetext{
Address for Correspondence: Mehmet KÖTEN

e-mail:

mehmetkoten@gmail.com
}

Received Date:

02.01.2021

Accepted Date:

04.02.2021

(C) Copyright 2018 by Harran University Faculty of Agriculture. Available on-line at www.dergipark.gov.tr/harranziraat
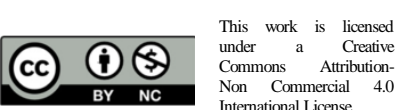

\section{Giriş}

Teknolojinin gelişmesi, yaşam tarzlarının değişimi, hayat kalitesinin artması ve tüketicilerin bilinçlenmesi, insanların besin ihtiyaçlarının ve
Bu çalışmada, mısır unu ilavesinin pandispanya tipi keklerin morfogeometrik, fonksiyonel ve tekstürel özelliklerine etkisi araştırılmıştır. Buğday unu ile mısır unu karışımları (100:00, 90:10, $80: 20,70: 30,60: 40,50: 50)$ hazırlanarak pandispanya tipi kek yapımında kullanılmışır. Farklı oranlarda mısır unu ilavesi ile keklerin nem, kül, yağ, toplam besinsel lif, toplam fenolik madde, antioksidan ve fitik asit içeriklerinin arttığı, protein içeriğinin düştüğü tespit edilmiştir. Kek örneklerinde mısır unu ilave oranlarının artması; kek hacmi, hacim indeksi, simetri indeksi ve pişme kaybı değerlerinin belirgin düzeyde azalmasına, kek yoğunluğunun ise artmasına neden olmuştur. Mısır unu ilavesi, keklerin esneklik ve iç yapışkanlık hariç diğer tüm tekstürel değerlerinde düşüşe neden olurken $L^{*}$ ve $b^{*}$ renk değerlerinde artışa neden olmuştur. Duyusal analizler sonucunda genel kabul edilebilirlik açııından en çok beğeniyi \%40 mısır unu ilaveli kek örneği alırken en az beğeniyi kontrol örneği almıştır.

Anahtar Kelimeler: Pandispanya, Kek kalitesi, Mısır unu, Morfogeometrik özellikler

\section{ABSTRACT}

In this study, the effect of corn flour addition on the morphogeometric, functional and textural properties of sponge type cakes was investigated. Wheat flour and corn flour mixtures $(100: 0,90: 10,80: 20,70: 30,60: 40,50: 50)$ were prepared and used in making sponge type cake. It was determined that moisture, ash, fat, total dietary fiber, total phenolic matter, antioxidant and phytic acid contents of cakes increased and protein contents decreased with the addition of corn flour in different ratios. Increased corn flour addition ratios in cake samples caused a significant decrease in cake volume, volume index, symmetry index and weight loss values, while an increase in cake density was observed. The addition of corn flour caused a decrease in all textural properties of the cakes except springiness and cohesiveness, and increased $\mathrm{L}^{*}$ and $\mathrm{b}^{*}$ color values. As a result of the sensory analysis, in terms of general acceptability, the cake sample with the addition of $40 \%$ corn flour received the highest like, while the least like was recorded for the control sample.

Key Words: Sponge cake, Cake quality, Corn flour, Morphogeometric properties beslenme alışkanlıklarının değişmesine neden olmuştur. Bu durum aynı zamanda gıdaları yalnızca temel intiyaçları karşılayan besin ögeleri olmaktan çıkartmış, endüstriyel anlamda daha zengin, kaliteli, raf ömrü uzun, sağlıklı, tekstürel 
ve duyusal özellikleri geliştirilmiş çeşitli gıdaların üretilmesi için yapılan çalışmaların hızla artmasına katkıda bulunmuştur. Tahıl ve ürünlerinin günlük beslenmede önemi oldukça büyük olup günlük diyetin büyük bir bölümü tahıl ve ürünlerinden karşılanmaktadır. Üretilen tahı ürünlerinin lezzetli ve tüketimlerinin pratik olması nedenleriyle özellikle kek, bisküvi gibi ürünler tüketicilerin dikkatini çekmektedir. Tüketicilerin bu talepleri karşısında tahıl ürünlerinde üretim ve ürün çeşitliliği de her geçen gün artmaktadır.

Unlu mamullerin günümüzdeki beslenme alışkanlıklarındaki artan önemi, bu gıda ürünlerinin tüketiciler tarafından kolayca kabul edilebileceği ve dolayısıyla önemli bileşenler için araç olarak kullanılabileceği anlamına gelmektedir. Kek yumuşak dokusu, tadı, yemeye hazır doğası, çeşitliliği ve uygun maliyeti nedeniyle tüm yaş grubu tüketiciler tarafından tercih edilen tatlı, yüksek kalorili pişmiş bir fırın ürünüdür (Kaur ve Kaur, 2018). Tüketimi gün geçtikçe artan ve pek çok ülkede unlu mamuller endüstrisinde ekmek ve bisküviden sonra en çok üretimi yapılan bir ürün konumundadır (Baltacıoğlu ve ark., 2020).

Mısır, içerdiği zengin besin maddeleri nedeniyle hem insan, hem de hayvan beslenmesi bakımından çok değerli ve kullanım çeşitliliği olan bir tahıl ürünüdür. Mısır, dünya tarım ürünleri piyasalarında hem üretim hem de ticareti ile oldukça önemli bir yere sahiptir. Sanayide, mısırdan pek çok ürün elde edilmektedir; un, yağ, nişasta, tatlandırıcılar başta olmak üzere, yüzlerce ürün sayılabilir. Mısırdan elde edilen ürünlerin her bir parçası, ayrı bir ekonomik değere sahiptir (Algül, 2012). Bazı yörelerimizde sadece mısırdan yapılan veya mısır ve buğday unu karışımından yapılan ekmekler oldukça yaygın olarak tüketilmektedir. Mısır unu, kurutulmuş mısır tanelerinin çok iyi bir şekilde öğütülmesiyle elde edilir, kokusuzdur ve yumuşak bir tadı vardır. Mısır unu, karbonhidrat ve nişasta bakımından zengin, protein ve vitamin bakımından ise fakirdir. Mısır unu birçok amaçla kullanılmaktadır. Ekmek yapımında, et ve balık pişirmede, dolgu macunu, yapıştırıcı olarak kullanım alanı bulmaktadır. Mısır unu veya diğer öğütme ürünleri şeklinde gıdalarda bileşen olarak yer alabilmektedir. Özellikle başka tür unlarla karıştırılıp değişik hamur işlerinin yapımında kullanımı da oldukça yaygındır (Algül, 2012; İnceer, 2011).

Tüketicilerin doğal katkılara, değişik tatlara ve fonksiyonel özellik gösteren sağııkı ürünlere yönelmesi ile gıda alanında yürütülen bilimsel çalışmalar da bu tür yeni gıdaların geliştirilmesi üzerine yoğunlaşmıştır. $\mathrm{Bu}$ nedenlerle bu çalışmada kek formülasyonuna mısır unu ilave etmek suretiyle; besin değeri ve lezzet bakımından zenginleştirilmiş yeni fonksiyonel bir kekin üretilmesi amaçlanmıştır. Çalışma kapsamında, mısır unu ilavesinin pandispanya tipi keklerin morfogeometrik, fonksiyonel ve tekstürel özelliklerine etkisi incelenmiştir.

\section{Materyal ve Metot}

\section{Materyal}

Kek üretiminde kullanılan buğday unu, mısır unu, pudra şekeri, vanilya, kabartma tozu, rafine kristal tuz ve yumurta Kilis'te yerel bir marketten satın alınmıştır. Araştırmada kullanılan jel yapıdaki yüzey aktif madde (yağ asitlerinin mono ve digliseritleri (E471) ile yağ asitlerinin poligliserit esterleri (E475)'nden oluşan) Katsan firması (İstanbul)'dan temin edilmiştir. Formülasyonda Kilis 7 Aralık Üniversitesi kampüsü su şebekesinden temin edilen içme suyu kullanılmıştır.

Kek hamuru formülasyonları, buğday ununun farklı oranlarda (100:0, 90:10, 80:20, 70:30, 60:40 ve 50:50) mısır unu ile karıştırılmasıyla hazırlanmıştır.

Araştırmada, hamur hazırlama işlemi için laboratuvarda bulunan $2 \mathrm{~kg}$ hamur kapasiteli ve 10 farklı karıştırma hızına sahip "Kitchen Aid" marka "KSM45" model mikser (KitchenAid Inc., St. Joseph, Michigan, USA) kullanılmıştır. Pişirme işleminde Amerikan Tahıl Kimyagerleri Birliği (AACC)'nin 10-90.01 nolu yönteminde açıklandığı gibi iç çapı $203 \mathrm{~mm}$ ve derinliği $38 \mathrm{~mm}$ olan paslanmaz çelik tavalardan yararlanılmış ve 2 pişirme bölmeli, üst iç yüzeyinde ısıtıcı rezistansı 
bulunan Arçelik marka SUF 4000 MEB model set üstü elektrikli fırın (Arçelik, Bolu, Türkiye) kullanılmıştır.

\section{Pandispanya formülü ve yapım yöntemi}

Kek hamurları "Materyal" bölümünde tanımlanan ve Çizelge 1'de verilen bileşenler kullanılarak hazırlanmıştır. Kek formülasyonunda mısır unu değişken bileşen olarak kullanılmıştır. Mısır unu buğday unu ile yer değiştirme prensibine göre $\% 10,20,30,40$ ve 50 oranlarında ikame edilerek kullanılırken, diğer bileşenler sabit miktarlarda kullanılmıştır. Sonuç olarak toplamda 6 farklı hamur formülasyonu oluşturulmuştur. Mısır unu içermeyen hamur ise kontrol kek üretmek için hazırlanmıştır.

Kek üretiminde Dizlek ve Özer (2017) tarafından bildirilen yöntem modifiye edilerek kullanılmıştır. Öncelikle kuru bileşenler (buğday unu, misır unu, kabartma tozu, vanilya, pudra şekeri ve tuz) kek hamuruna ilave edilmeden önce birbiri içerisinde iyice karıştırılarak homojen hale getirilmiştir. Kek hamuru hazırlanırken bileşenlerin karıştırılmasında şu sıra takip edilmiştir. Illk olarak yumurta, mikserin 4 hız ayarında $1 \mathrm{dk}$ çırpılmış daha sonra yüzey aktif madde ve su ilave edilerek $1 \mathrm{dk}$ daha aynı hızda karıştırılmıştır. Bu karışıma homojen hale getirilmiş kuru bileşenler ilave edilerek karıştırmaya mikserin $6 \mathrm{hız}$ ayarında $3 \mathrm{dk}$ daha devam edilmiştir. Bu karıştırma işleminin sonunda elde edilen hamurlar $500 \mathrm{~g}$ tartılmak suretiyle yağ ile kaplanmış pişirme tavalarına konulmuştur. Kek hamurları $230 \pm 3{ }^{\circ} \mathrm{C}$ 'de fırının (Arçelik marka, SUF 4000 MEB model set üstü elektrikli fırın) alt pişme modunda $30 \mathrm{dk}$, üst-alt pişirme modunda $6 \mathrm{dk}$ olmak üzere toplamda $36 \mathrm{dk}$ pişirilmiştir. Pişirme işleminin ardından kekler $10 \mathrm{dk}$ boyunca kendi pişirme kaplarında soğutulmaya bırakılmıştır. Daha sonra kekler tavalarından çıkarılıp tel raflarda 30 dk oda sıcaklığına kadar soğutulmuştur. Son olarak, kekler analiz zamanına kadar tel raflar üzerinde kapaklı polietilen kaplarda ahşap dolaplarda tutulmuştur. Araştırmada uygulanan karıştırma ve pişirme süreleri ile pişirme sıcaklığı ön denemelerle belirlenmiştir. Üretilen keklere ait fotoğraflar Şekil 1 'de gösterilmiştir.

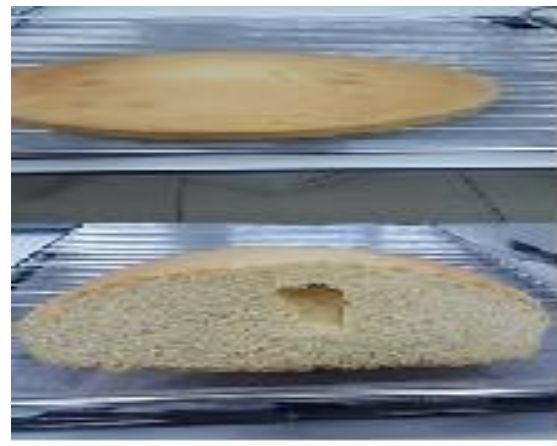

$\% 0$

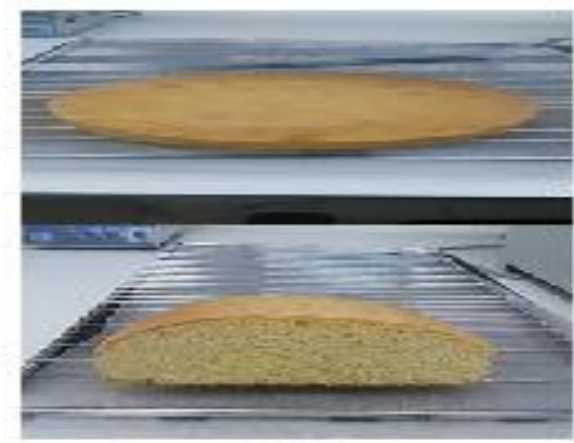

$\% 30$

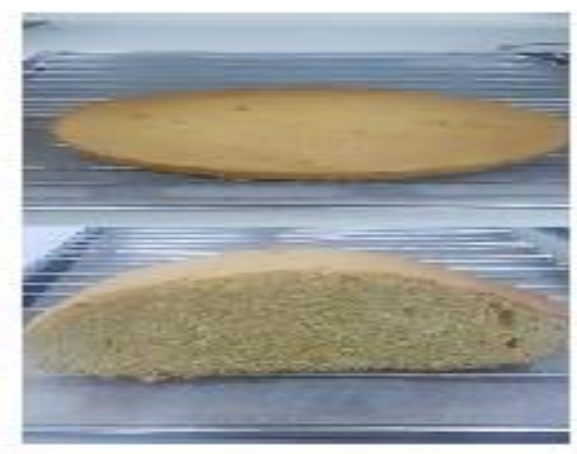

$\% 10$

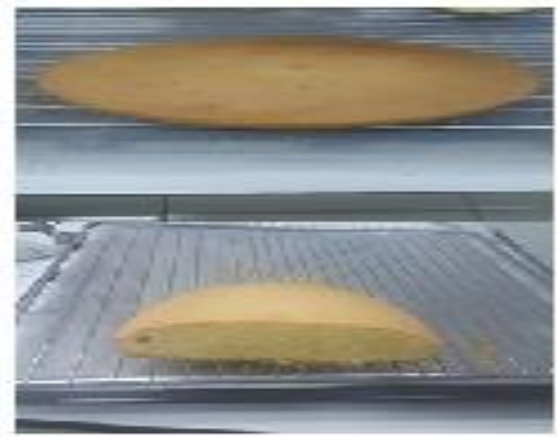

$\% 40$

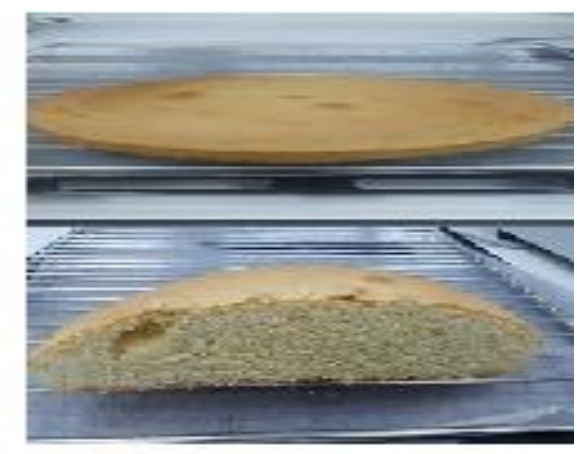

920

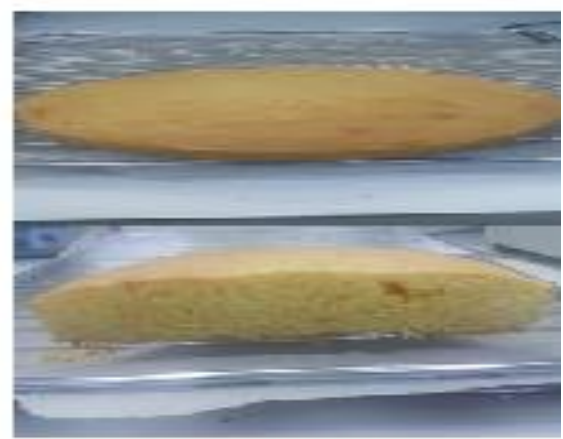

$\% 50$

Şekil 1. Farklı oranlarda mısır unu ilaveli pandispanyalar

Figure 1. Sponge cakes with corn flour addition in different ratios 
Çizelge 1. Kek hamuru formülasyonu

Table 1. Cake batter formulation

\begin{tabular}{|c|c|}
\hline $\begin{array}{l}\text { Bileşenler } \\
\text { Ingredients }\end{array}$ & $\begin{array}{c}\text { Miktar (g) } \\
\text { Quantitiy (g) }\end{array}$ \\
\hline Buğday unu* & 100 \\
\hline \multicolumn{2}{|l|}{ Wheat flour ${ }^{*}$} \\
\hline Mısır unu ${ }^{* *}$ & $10-50$ \\
\hline \multicolumn{2}{|l|}{ Corn flour ${ }^{* *}$} \\
\hline Şeker ${ }^{*}$ & 72 \\
\hline \multicolumn{2}{|l|}{ Sugar ${ }^{*}$} \\
\hline Yumurta* & 60 \\
\hline \multicolumn{2}{|l|}{$\mathrm{Egg}^{*}$} \\
\hline $\mathrm{Su}^{*}$ & 30 \\
\hline \multicolumn{2}{|l|}{ Water $^{*}$} \\
\hline Yüzey aktif madde* & 10 \\
\hline \multicolumn{2}{|l|}{ Surfactant ${ }^{*}$} \\
\hline Kabartma tozu ${ }^{*}$ & 2 \\
\hline \multicolumn{2}{|l|}{ Baking powder* } \\
\hline Vanilya* $^{*}$ & 1 \\
\hline \multicolumn{2}{|l|}{ Vanilla* } \\
\hline Tuz $^{*}$ & 0.5 \\
\hline Salt $^{*}$ & \\
\hline
\end{tabular}

*Değişken miktarlarda. Çizelgede verilen miktarlar mısır unu içermeyen kontrol örneği için geçerlidir.

*Variable quantities. The quantities given in the table apply to the control sample that does not contain corn flour.

${ }^{* *}$ Buğday unu ile yer değiştirme prensibine göre $\% 10,20,30,40$ ve 50 (w/w) oranlarında kullanılmıştır.

${ }^{* *}$ It was used in the ratios of 10, 20,30, 40 and $50 \%(w / w)$ according to the principle of replacing with wheat flour.

\section{Kimyasal analizler}

Buğday unu, mısır unu ve kek örneklerinin nem (metot 44-19.01), kül (metot 08-01.01), protein (metot 46-12.01) ve yağ (metot 30-25.01) içeriklerinin belirlenmesinde AACC metotları kullanılmıştır (AACC, 2010).

\section{Morfogeometrik analizler}

Kek örneklerinin hacim indeksi, simetri indeksi, tekdüzelik indeksi, toplam hacim indeksi ve pişme kaybı analizleri Dizlek ve Özer (2017)'nin bildirdiği yönteme göre gerçekleştirilirken; hacim ve spesifik hacim analizleri Dizlek (2015)'in bildirdiği yönteme göre gerçekleştirilmiştir. Kek yoğunluğu ise, kekin ağırlığı ile hacmi arasındaki oran olarak hesaplanmıştır.

\section{Fonksiyonel özellikler}

Toplam besinsel lif (TBL)

Buğday unu, mısır unu ve kek örneklerinde yapılmıştır. Yöntemde toplam besinsel lif test kiti (Megazyme International Ireland Ltd., Bray Business Park, Bray, Co. Wicklow, Ireland) kullanılmıştır. Yöntem, Lee ve ark. (1992), Prosky ve ark. (1992), Prosky ve ark. (1988) tarafından geliştirilen yöntemdir.

\section{Toplam fenolik madde (TFM)}

Buğday unu, mısır unu ve keklerde Aktaş ve Levent (2018)'in bildirdiği metoda göre FolinCiocalteu reaktifi kullanılarak belirlenmiştir. Örnekler \%80 metanol ile ekstrakte edilmiştir. Bunun için $1 \mathrm{~g}$ örnek, $10 \mathrm{ml} \% 80$ sulu metanol ile 2 saat süreyle $37^{\circ} \mathrm{C}^{\prime}$ de çalkalanarak ekstrakte edilmiştir. Daha sonra örnek 2600 g'de 15 dakika santrifüjlenmiştir. Taze metanolik extrakt, toplam fenolik madde içeriğini belirlemek için kullanılmıştır. TFM içeriği; önceden gallik asit ile oluşturulan (absorbans / konsantrasyon) standart grafiğinden elde edilen denklem ile hesaplanmış ve sonuçlar $1 \mathrm{~kg}$ örnek için mg gallik asit eşdeğer (GAE) miktarı olarak ifade edilmiştir.

\section{Antioksidan aktivite}

Buğday unu, mısır unu ve keklerde Aktaş ve Levent (2018)'in bildirdikleri metot modifiye edilerek kullanılmıştır. Örnekler saf metanol ile ekstrakte edilmiştir. Bunun için $0.1 \mathrm{~g}$ örnek, $3 \mathrm{ml}$ saf metanol ile 1 saat süreyle çalkalanarak ekstrakte edilmiştir. Daha sonra örnek 2600 g'de 20 dakika santrifüjlenmiştir. Taze metanolik ekstrakt, DPPH (2,2-difenil-1-pikrilhidrazil) radikalini temizleme yeteneğini belirlemek için kullanılmıştır. Bu yöntem, pembe renkli stabil bir bileşik olan DPPH (2,2-diphenyl-1-picrylhdrazyl) radikalinin yok edilmesi sonucu, renkte meydana gelen azalmanın spektrofotometrik olarak ölçülmesi esasına dayanmaktadır. Sonuçlar DPPH radikalinin inhibisyon oranı şeklinde denklem 1 kullanılarak hesaplanmıştır.

DPPH radikalinin inhibisyon oranı $(\%)=\left[\left(A_{\text {kör- }}-A_{\text {örnek }}\right) / A_{\text {kör }}\right] \times 100$

Burada;

AKör $=$ Körün absorbansı

Aörnek = Örneğin absorbansı

Fitik asit

Örneklerdeki fitik asitin $\mathrm{Fe}^{+3}$ ile çözünmez formu olan demirfitat şeklinde çöktürülüp arta 
kalan yani çökelmeyen $\mathrm{Fe}^{+3}$ miktarının bipyridine ile oluşturduğu rengin spektrofotometrik olarak ölçülmesi esasına dayalı bir yöntem kullanılmıştır. Bu ölçüm miktarı ile fitik asite bağlanıp çöken $\mathrm{Fe}^{+3}$ miktarı da dikkate alınarak fitik asit konsantrasyonu hesaplanmaktadır (Haug ve Lantzsch, 1983).

\section{Renk analizleri}

Buğday unu, mısır unu ve kek örneklerinin renk ölçümleri Hunterlab MiniScan EZ (Reston, Virginia, USA) model renk ölçüm cihazıyla yapılmış ve değerler yine bu cihazda CIALAB ölçüm sistemine göre ifade edilmiştir. HunterLab renk skalasında $L^{*}=0$ (siyah), $L^{*}=100$ (beyaz); - $a^{*}$ (yeşillik), +a* (kırmızılık); -b* (mavilik), +b* (sarılık) değerleri gün ışığı $\left(D 65 / 10^{\circ}\right)$ ayarında okunmuştur. Renk ölçümleri 3 paralelli yapılmış ve sonuç üç değerin ortalaması olarak verilmiştir.

\section{Tekstürel özellikler}

Tekstürel özellikler AACC metot 74-09.01 (AACC, 2010) esas alınarak TA-XT Plus tekstür analiz cihazında (Stable Micro Systems, Godalming, Surrey, UK) tespit edilmiştir. Bu amaçla P/36R donanımı kullanılarak keklerden 5 $\mathrm{mm}$ çap ve $20 \mathrm{~mm}$ yüksekliğinde sonda ile alınan örneklere Tekstür Profil Analizi (TPA) uygulanmıştır. Elde edilen kuvvet-zaman eğrisinden sertlik, esneklik, yapışkanlık, iç yapışkanlık ve çiğnenebilirlik değerleri hesaplanmıştır. Testin yapıldığı mekaniksel şartlar (test parametreleri) cihazda aşağıdaki gibi ayarlanmıştır:

Pre-test speed: $1 \mathrm{~mm} / \mathrm{s}$

Test speed: $1 \mathrm{~mm} / \mathrm{s}$

Post-test speed: $10 \mathrm{~mm} / \mathrm{s}$

Test distance: $5 \mathrm{~mm}$

Trigger type: Auto (Force)

Trigger Force: $0.049 \mathrm{~N}$

\section{Duyusal analiz}

Volpini-Rapina ve ark. (2012) ve Emmanuel ve ark. (2013)'nın bildirdikleri metotlar modifiye edilerek kullanılmıştır. Duyusal analiz yarı eğitilmiş 10 panelist tarafından
Panelistlerden kek örneklerini kek dış rengi, kek iç rengi, gözenek yapısı, tekstür (kek yumuşaklığı), tat-aroma, ağız hissi özellikleri ve genel kabul edilebilirlik açısından; 1-5 arasındaki skala (1-çok kötü, 2-kötü, 3-orta, 4-iyi ve 5-çok iyi) kullanılarak duyusal değerlendirme yapmaları istenmiştir.

\section{istatistiksel analizler}

İki tekerrürlü olarak yürütülen çalışmada elde edilen tüm veriler ortalama \pm standart sapma şeklinde ifade edilmiştir. Kek örnekleri arasında gözlemlenen varyasyonların önemi, JMP 11.0 (SAS Institute Inc., Cary, NC, ABD) yazılım programı kullanılarak test edilmiştir. Farklılıkları istatistiki olarak önemli bulunan ana varyasyon kaynaklarının ortalamaları $\mathrm{P} \leq 0.05$ düzeyinde Tukey HSD testi ile karşılaştırılmıştır.

\section{Araştırma Bulguları ve Tartışma}

\section{Hammadde özellikleri}

Kek formülasyonunda kullanılan buğday unu ve mısır ununun yaklaşık bileşimlerinin sonuçları Çizelge 2'de verilmiştir. Mısır ununun buğday unundan daha yüksek kül, yağ, TBL, TFM, antioksidan aktivite ve fitik asit değerlerine sahip olduğu saptanmıştır. Bu da mısır ununun zengin kimyasal kompozisyonu ile kekin besinsel kalitesinin arttırılması açısından uygun olduğunu göstermiştir. Mısır ununun nem, kül, protein ve yağ içeriği sırasıyla \% 10.79, \% 1.28, \% 7.78 ve \% 2.33 olarak bulunmuştur. Buğday ununun kül, protein, yağ ve TFM içerikleri sırasıyla \% 0.63, \% $10.81, \% 1.19$ ve 934.86 mg kg-1 olarak tespit edilmiştir. Bu değerler Kaur ve Kaur (2018)'un bildirdiği sonuçlara yakın bulunmuştur. Çizelgeden de görüleceği üzere mısır ununun, TBL değeri \%3.34, TFM değeri $1063.96 \mathrm{mg} \mathrm{kg}^{-1}$, antioksidan aktivite değeri \% 9.93 ve fitik asit değeri $2.48 \mathrm{mg}$ $\mathrm{g}^{-1}$ olarak belirlenmiştir. Argun (2016) yaptığı çalışmasında At dişi ve Sert mısır çeşitlerinde toplam fenolik madde miktarını 1304.70-2521.50 $\mathrm{mg} \mathrm{kg}{ }^{-1}$, antioksidan aktivite değerini \%22-39 ve fitik asit değerini 7.33-9.57 $\mathrm{mg} \mathrm{kg}^{-1}$ aralıklarında saptamıştır. Çalışmamızda saptanan değerlerin bu sonuçlardan düşük çıkmasının nedeninin mısır 
ununun elde edildiği mısır çeşidinin ve yetiştirildiği toprak ve iklim koşullarının farklı olmasından kaynaklandığı söylenebilir.

Buğday ununa ait $L^{*}$ değerinin mısır unundan daha yüksek, $a^{*}$ ve $b^{*}$ değerlerinin mısır unundan daha düşük olduğu tespit edilmiştir (Çizelge 2). Mısır ununa ait renk değerleri incelendiğinde buğday ununa göre daha sarı, daha kırmızı ve daha parlak olduğu görülmüştür. Mısır ununun nem, protein ve renk değerlerine ilişkin bulunan sonuçlar Kılınççeker ve Hepsağ (2010) tarafından bildirilen sonuçlarla uyumlu bulunmuştur.

\section{Kek özellikleri}

Kimyasal ve fonksiyonel özellikler

Mısır unu katkılı pandispanyaların kimyasal ve fonksiyonel özelliklerine ait veriler Çizelge 3'te sunulmuştur. Örneklerin 1. gün nem içerikleri mısır unu ilavesi ile kontrol örneğine göre artış göstermiştir. 2. gün yapılan nem analizi sonuçlarına bakıldığında ise ilk gün analiz sonuçlarından düşük bulunmuş ve yine mısır unu ilave oranının artışına bağlı olarak artmıştır $(P \leq 0.05)$. Kek formülasyonuna ilave edilen mısır unu oranı arttıkça kek örneklerinin protein içeriği hariç kül, yağ, TBL, TFM, antioksidan aktivite ve fitik asit içeriklerinde önemli derecede artış görülmüştür ( $P \leq 0.05)$.

Buğday ununa göre mısır ununda saptanan yüksek kül, yağ, TBL, TFM ve antioksidan içerikleriyle (Çizelge 2) ilişkili olarak keklerdeki saptanan değerlerin yüksek çıkması beklenen bir durumdur. Çizelge 3'te görüldüğü üzere en düşük kül içeriği (\%1.32) kontrol örneğinde tespit edilirken, en yüksek kül içeriği (\%1.59) \%50 mısır unu ilaveli örnekte tespit edilmiştir. Protein içeriği kontrol kekinde \% 9.55 olarak belirlenirken, mısır unu ilaveli keklerde \%7.79-10.52 arasında değişmiştir. En fazla yağ içeriği ise \%7 değeri ile \%50 mısır unu ilaveli örnekte bulunmuştur. Kek örneklerinin toplam fenolik madde, antioksidan aktivite, ve toplam besinsel lif değerleri sırasıyla 84.50-126.33 mg kg-1, \%9.79-20.74, \%2.96-6.10 aralıklarında artan mısır oranı ile artmıştır (Çizelge 3). Keten tohumu, ayçiçeği tohumu, brokoli yaprağı, ve kinoa unu gibi doğal bileşenlerin kullanıldığı kek çalışmalarında da benzer sonuçlar bildirilmiştir (Kaur ve ark., 2020; Grasso ve ark., 2019; Drabinska ve ark., 2018; Aktaş ve Levent, 2018).

Çizelge 2. Buğday unu ve mısır ununun özellikleriף Table 2. Properties of wheat flour and corn flour"

\begin{tabular}{|c|c|c|}
\hline $\begin{array}{l}\text { Özellik } \\
\text { Property }\end{array}$ & $\begin{array}{l}\text { Buğday unu } \\
\text { Wheat flour }\end{array}$ & $\begin{array}{l}\text { Misır unu } \\
\text { Corn flour }\end{array}$ \\
\hline $\begin{array}{l}\text { Nem (\%) } \\
\text { Moisture (\%) }\end{array}$ & $11.52 \pm 0.15^{a}$ & $10.79 \pm 0.18^{b}$ \\
\hline $\begin{array}{l}\text { Kül }(\% w / w)^{+} \\
\text {Ash }(\% w / w)^{+}\end{array}$ & $0.63 \pm 0.04^{b}$ & $1.28 \pm 0.06^{\mathrm{a}}$ \\
\hline $\begin{array}{l}\text { Protein }(\% w / w)^{+} \\
\text {Protein }(\% w / w)^{+}\end{array}$ & $10.81 \pm 0.26^{a}$ & $7.78 \pm 0.09^{b}$ \\
\hline $\begin{array}{l}\text { Toplam yağ }(\% \mathrm{w} / \mathrm{w})^{+} \\
\text {Total fat }(\% \mathrm{w} / \mathrm{w})^{+}\end{array}$ & $1.19 \pm 0.03^{b}$ & $2.33 \pm 0.08^{a}$ \\
\hline $\begin{array}{l}\text { TBL }(\% w / w)^{\dagger \neq} \\
T D F(\% w / w)^{+\ddagger}\end{array}$ & $1.97 \pm 0.05^{b}$ & $3.34 \pm 0.07^{a}$ \\
\hline $\begin{array}{l}\text { TFM }\left(\mathrm{mg} \mathrm{kg}^{-1}\right)^{\dagger \S} \\
\text { TPM }\left(m g \mathrm{~kg}^{-1}\right)^{\dagger \S}\end{array}$ & $934.86 \pm 12.22^{\mathrm{a}}$ & $1063.96 \pm 16.07^{a}$ \\
\hline $\begin{array}{l}\text { Antioksidan aktivite } \\
\text { (\% inhibisyon) } \\
\text { Antioxidant activity } \\
\text { (\% inhibition) }\end{array}$ & $11.13 \pm 0.13^{a}$ & $9.93 \pm 0.08^{b}$ \\
\hline $\begin{array}{l}\text { Fitik asit }\left(\mathrm{mg} \mathrm{g}^{-1}\right)^{+} \\
\text {Phytic acid }\left(\mathrm{mg} \mathrm{g}^{-1}\right)^{+}\end{array}$ & $1.35 \pm 0.06^{b}$ & $2.48 \pm 0.04^{\mathrm{a}}$ \\
\hline $\begin{array}{l}L^{*} \\
L^{*}\end{array}$ & $90.99 \pm 0.76^{a}$ & $88.68 \pm 0.75^{b}$ \\
\hline$a^{*}$ & $0.63 \pm 0.01^{b}$ & $3.07 \pm 0.03^{a}$ \\
\hline $\begin{array}{l}\mathrm{b}^{*} \\
b^{*}\end{array}$ & $9.90 \pm 0.23^{b}$ & $28.29 \pm 0.09^{a}$ \\
\hline \multicolumn{3}{|c|}{$\begin{array}{l}\text { "Çizelgede, aynı satırda farklı harfle gösterilen değerler arasındaki farklar } \\
0.05 \text { güven sınırına göre önemlidir. } \\
\text { "In the table, differences between values shown with different letters in the } \\
\text { same line are significant compared to the } 0.05 \text { confidence level. } \\
{ }^{\dagger} \text { Kuru madde üzerinden hesaplanmıştır. } \\
{ }^{+} \text {Calculated on dry matter bases. } \\
{ }^{\ddagger} \text { Toplam besinsel lif, }{ }^{\ddagger} \text { Total dietary fiber } \\
{ }^{5} \text { Toplam fenolik madde, }{ }^{5} \text { Total phenolic matter }\end{array}$} \\
\hline
\end{tabular}

Kek örneklerinin fitik asit içeriği 0.94-1.34 mg $\mathrm{kg}^{-1}$ arasında değişmiştir. Beklendiği gibi, mısır unu kullanımı keklerin fitik asit içeriğinde önemli artışa neden olmuştur. Fitik asit, mineralleri, proteinleri ve nişastayı dolaylı veya doğrudan bağlayabilmesi nedeniyle bir antinutrient olarak kabul edilir. Bu bağlanma, bu besinlerin biyoyararlanımını veya sindirilebilirliğini olumsuz etkilemektedir. Bununla birlikte, fitik asidin antioksidan ve antikarsinojenik etkiler dâhil olmak üzere bazı sağlıklı etkileri birçok araştırmacı tarafından bildirilmiştir. Ancak, yararlı etkiler ortaya çıkarmak için insanlar için dozaj bilgisi sınırlıdır (Aktaş ve Levent, 2018). 
Çizelge 3. Kek örneklerinin kimyasal ve fonksiyonel özellikleriף

Table 3. Chemical and functional properties of cake samples"

Özellikler

Properties

Nem (1. gün) (\%)

Moisture (1st day)(\%)

Nem (2. gün) (\%)

Moisture (2nd day)(\%)

Kül $(\%)^{\dagger}$

Ash $(\% w / w)^{+}$

Protein $(\% w / w)^{+}$

Protein $(\% w / w)^{\dagger}$

Toplam yağ $(\% w / w)^{+}$

Total fat $(\% w / w)^{\dagger}$

TFM $\left(\mathrm{mg} \mathrm{kg}^{-1}\right)^{+\S}$

TPM $\left(m g \mathrm{~kg}^{-1}\right)^{\dagger \S}$

Antioksidan aktivite

(\% inhibisyon)

Antioxidant activity

(\% inhibition)

TBL $(\%)^{\dagger \neq}$

TDF $(\% w / w)^{\dagger \ddagger}$

Fitik asit $\left(\mathrm{mg} \mathrm{g}^{-1}\right)$

Phytic acid $\left(\mathrm{mg} \mathrm{g}^{-1}\right)^{+}$

\begin{tabular}{|c|c|c|c|c|c|}
\hline \multicolumn{6}{|c|}{$\begin{array}{l}\text { Mısır unu oranı }(\% \mathrm{w} / \mathrm{w}) \\
\text { Corn flour ratio }(\% \mathrm{w} / \mathrm{w})\end{array}$} \\
\hline 0 & 10 & 20 & 30 & 40 & 50 \\
\hline $28.27 \pm 0.68^{b}$ & $28.51 \pm 0.59^{b}$ & $29.05 \pm 0.43^{\mathrm{ab}}$ & $29.58 \pm 0.44^{\mathrm{ab}}$ & $29.78 \pm 0.36^{\mathrm{ab}}$ & $31.65 \pm 1.54^{a}$ \\
\hline $27.44 \pm 0.38^{c}$ & $27.83 \pm 0.16^{b c}$ & $28.59 \pm 0.83^{\mathrm{abc}}$ & $29.00 \pm 0.45^{a b c}$ & $29.31 \pm 0.20^{\mathrm{ab}}$ & $29.59 \pm 0.49^{a}$ \\
\hline $1.32 \pm 0.01^{c}$ & $1.34 \pm 0.01^{c}$ & $1.38 \pm 0.01^{b c}$ & $1.43 \pm 0.01^{b}$ & $1.52 \pm 0.03^{\mathrm{a}}$ & $1.59 \pm 0.04^{a}$ \\
\hline $9.55 \pm 0.12^{b}$ & $10.52 \pm 0.05^{\mathrm{a}}$ & $9.33 \pm 0.11^{c}$ & $8.76 \pm 0.08^{d}$ & $8.14 \pm 0.06^{e}$ & $7.79 \pm 0.03^{f}$ \\
\hline $5.48 \pm 0.09^{e}$ & $5.85 \pm 0.01^{d}$ & $6.02 \pm 0.04^{c}$ & $6.47 \pm 0.11^{b}$ & $6.86 \pm 0.06^{a}$ & $7.00 \pm 0.02^{\mathrm{a}}$ \\
\hline $84.5 \pm 0.25^{f}$ & $88.99 \pm 0.20^{e}$ & $101.50 \pm 0.14^{d}$ & $109.55 \pm 0.52^{c}$ & $118.22 \pm 0.31^{b}$ & $126.33 \pm 0.14^{a}$ \\
\hline $9.79 \pm 0.11^{d}$ & $11.40 \pm 0.40^{\mathrm{d}}$ & $13.68 \pm 0.62^{c}$ & $16.57 \pm 0.55^{b}$ & $18.04 \pm 0.21^{b}$ & $20.74 \pm 0.35^{a}$ \\
\hline $2.96 \pm 0.04^{\mathrm{e}}$ & $4.04 \pm 0.08^{d}$ & $4.56 \pm 0.16^{c}$ & $5.02 \pm 0.11^{b}$ & $5.44 \pm 0.06^{b}$ & $6.10 \pm 0.07^{a}$ \\
\hline $0.94 \pm 0.06^{c}$ & $1.02 \pm 0.04^{\mathrm{bc}}$ & $1.14 \pm 0.08^{\mathrm{abc}}$ & $1.22 \pm 0.05^{\mathrm{ab}}$ & $1.29 \pm 0.02^{\mathrm{a}}$ & $1.34 \pm 0.04^{\mathrm{a}}$ \\
\hline
\end{tabular}

"Çizelgede, aynı satırda farklı harfle gösterilen değerler arasındaki farklar 0.05 güven sınırına göre önemlidir.

"In the table, differences between values shown with different letters in the same line are significant compared to the 0.05 confidence level.

${ }^{\dagger}$ Kuru maddede hesaplanmıştır.

${ }^{+}$Calculated on dry matter.

*Toplam besinsel lif, ₹Total dietary fiber

`Toplam fenolik madde, ${ }^{\S}$ Total phenolic matter

\section{Morfogeometrik özellikler}

Dış görünüş bakımından kekin en önemli ölçütü hacimdir. Kek üretiminde hacim indeksi değeri, keklerin gerçek hacmini ölçmemekle beraber, keklerin hacimleri hakkında fikir verir. Simetri indeksi, keklerin üst yüzlerinin yüzey görünümünü belirlemek için kullanılır. Simetri indeksi değerinin negatif (-) olması kekin çökük (içe doğru bombeli), sıfıra yakın olması kek yüzeyinin düz (bombesiz), pozitif (+) olması ise kek üst yüzeyinin kabarık (bombeli) olduğunu işaret eder. Tekdüzelik indeksi, keklerin yanal olarak simetrisini belirlemek için kullanılır ve bu değerin sıfır ya da sıfıra olabildiğine yakın olması istenir (Ijpek ve Dizlek, 2018). Mısır unu ilave edilmesi ile keklerin morfogeometrik özelliklerinde meydana gelen değişikliklere ilişkin veriler Çizelge 4'te gösterilmiştir. Kek örneklerinde, mısır unu oranının artması tekdüzelik indeksi dışındaki tüm diğer morfogeometrik özelliklerde belirgin düzeyde düşüşe neden olmuştur $(P \leq 0.05)$. Daha yüksek kek hacmi, daha fazla hava kabarcığı ve $\mathrm{CO}_{2}$ tutabilen yüksek hamur kıvamı ve viskozitesiyle ilişkilidir (Majzoobi ve ark., 2016). Genel olarak, düşük hacimli kekler düşük simetri indeksi göstermektedir (De la Hera ve ark., 2012). Mısır unu ilaveli pandispanyaların hacim değerlerindeki düşüşün; mısır unu ilavesiyle kek hamurunda oluşan zayıf gluten ağı ile birlikte hava kabarcıklarını tutan yapının zayıflamasından kaynaklandığı düşünülmektedir. Hacim indeksi değerlerinin hacim değerleriyle uyum içerisinde olduğu saptanmıştır (Çizelge 4). Bu sonuç, keklerin hacim ve hacim indeksleri arasında doğrusal ilişki olduğunu bildiren literatürlerle de uyumlu bulunmuştur (Dizlek ve Altan, 2015; Gomez ve ark., 2008).

Farklı oranlarda mısır unu kullanılarak üretilen pandispanya kek örneklerinin simetri indeks değerleri kontrol örneğinden düşük ama pozitif (+) bulunmuştur. Buna göre kek örneklerinin çökük bir yapıda olmadıkları görülmüştür. Benzer sonuçlar Majzoobi ve ark., (2016) tarafından yapılan çalışmada rapor edilmiştir. Tekdüzelik indeksi, iki eşit parçaya bölünen kekin merkez noktasından sağ ve sol yanlarına eşit uzaklıktaki iki noktanın yüksekliklerinin farkı alınarak ölçülür (Ijpek ve Dizlek, 2018; Dizlek ve Özer, 2017). Yapılan ölçümler sonucunda mısır unu ilave oranı arttıkça bu farkın kontrol kekine göre azaldığı bu 
durumun istatistiksel açıdan önemsiz olduğu saptanmıştır $(P>0.05)$.

Kek örneklerinin spesifik hacim değerleri mısır unu ilavesiyle değişim göstermiş ve bu değişimi istatistiksel açıdan da önemli bulunmuştur $(P \leq 0.05)$. Artan mısır unu oranı ile spesifik hacim değerleri azalmıştır. Kontrol kekinde bu değer 2.56 olarak bulunurken, mısır unu ilaveli keklerde oran artışına bağlı olarak 1.72'den 1.36'ya düşmüştür. Morfogeometrik özelliklerde bulunan tüm sonuçlar keten tohumu unu (Kaur ve ark., 2020), patates unu (Gerçekaslan ve Boz, 2020), soya unu (Dhen ve ark., 2016) ve nohut unu (Gomez ve ark., 2008) ilaveli kek çalışmalarında bildirilen sonuçlarla yakın ve benzer bulunmuştur.

Çizelge 4. Kek örneklerinin morfogeometrik özellikleriף

Table 4. Morphogeometric properties of cake samples"

\begin{tabular}{|c|c|c|c|c|c|c|}
\hline \multirow{2}{*}{$\begin{array}{l}\text { Özellikler } \\
\text { Properties }\end{array}$} & \multicolumn{6}{|c|}{$\begin{array}{l}\text { Mısır unu oranı }(\% \mathrm{w} / \mathrm{w}) \\
\text { Corn flour ratio }(\% \mathrm{w} / \mathrm{w})\end{array}$} \\
\hline & 0 & 10 & 20 & 30 & 40 & 50 \\
\hline $\begin{array}{l}\text { Hacim }\left(\mathrm{cm}^{3}\right) \\
\text { Volume }\left(\mathrm{cm}^{3}\right)\end{array}$ & $1504.16 \pm 2.04^{a}$ & $1451.76 \pm 2.83^{b}$ & $1423.76 \pm 1.41^{\mathrm{c}}$ & $1401.96 \pm 2.22^{d}$ & $1391.73 \pm 1.43^{e}$ & $1352.80 \pm 1.19^{f}$ \\
\hline $\begin{array}{l}\text { Spesifik hacim }\left(\mathrm{cm}^{3} \mathrm{~g}^{-1}\right) \\
\text { Specific volume }\left(\mathrm{cm}^{3} \mathrm{~g}^{-1}\right)\end{array}$ & $3.51 \pm 0.01^{\mathrm{a}}$ & $3.48 \pm 0.01^{a}$ & $3.37 \pm 0.00^{b}$ & $3.29 \pm 0.03^{c}$ & $3.24 \pm 0.01^{c}$ & $3.09 \pm 0.03^{d}$ \\
\hline $\begin{array}{l}\text { Hacim indeksi }(\mathrm{mm}) \\
\text { Volume index }(\mathrm{mm})\end{array}$ & $156.00 \pm 2.83^{a}$ & $151.50 \pm 0.71^{\mathrm{ab}}$ & $149.00 \pm 1.41^{\mathrm{ab}}$ & $144.00 \pm 2.83^{b c}$ & $\underset{c}{140.00 \pm 1.41}$ & $137.50 \pm 2.12^{c}$ \\
\hline $\begin{array}{l}\text { Simetri indeksi }(\mathrm{mm}) \\
\text { Symmetry index }(\mathrm{mm})\end{array}$ & $21.00 \pm 1.41^{\mathrm{a}}$ & $17.50 \pm 2.12^{\mathrm{ab}}$ & $15.00 \pm 1.41^{b c}$ & $10.50 \pm 0.71^{\mathrm{cd}}$ & $7.50 \pm 2.12^{d}$ & $6.00 \pm 0.00^{d}$ \\
\hline $\begin{array}{l}\text { Tekdüzelik indeksi (mm) } \\
\text { Uniformity index ( } \mathrm{mm})\end{array}$ & $0.10 \pm 0.14^{b}$ & $0.25 \pm 0.35^{\mathrm{ab}}$ & $0.40 \pm 0.00^{\mathrm{ab}}$ & $0.65 \pm 0.35^{a}$ & $0.25 \pm 0.21^{\mathrm{ab}}$ & $0.20 \pm 0.00^{b}$ \\
\hline $\begin{array}{l}\text { Pişme kaybı }(\% \mathrm{w} / \mathrm{v}) \\
\text { Weight Loss }(\% \mathrm{w} / \mathrm{v})\end{array}$ & $12.10 \pm 0.06^{d}$ & $14.43 \pm 0.21^{\mathrm{a}}$ & $14.07 \pm 0.06^{\mathrm{ab}}$ & $13.65 \pm 0.12^{b}$ & $12.81 \pm 0.15^{c}$ & $11.37 \pm 0.16^{\mathrm{e}}$ \\
\hline
\end{tabular}

"Çizelgede, aynı satırda farklı harfle gösterilen değerler arasındaki farklar 0.05 güven sınırına göre önemlidir.

$\pi$ In the table, differences between values shown with different letters in the same line are significant compared to the 0.05 confidence level.

\section{Renk özellikleri}

Mısır unu ilave edilerek üretilen keklerin kabuk ve iç rengi özelliklerine ilişkin bulgular Çizelge 5'te verilmiştir.

Çizelgede de görüldüğü üzere; kontrol örneğinin kabuk ve iç renk $L^{*}$ (parlaklık) değerlerinin daha düşük olduğu, mısır unu ilavesiyle kek örneklerinin $L^{*}$ ve $b^{*}$ (sarılık) değerlerinin istatistiki olarak önemli düzeyde $(P \leq 0.05)$ arttığı saptanmıştır. Ayrıca mısır unu ilavesiyle keklerin kabuk a* (kırmızılık) değerlerinin azaldığı ve iç $a^{*}$ değerlerinin arttığı belirlenmiştir. Dolayısıyla mısır unu ilavesi ve ilave oranındaki artışlar, keklerin daha parlak ve sarı renge sahip olmasına neden olmuştur. Kek içi ve kabuk $a^{*}$ değerleri arasındaki farklılıkların istatistiksel olarak önemli olduğu $(P \leq 0.05)$ bulunmuştur (Çizelge 5). Mısır unu ilavesiyle keklerin iç dokularında parlaklık ile sarılığın artmasının mısır ununun kendine has renginden kaynaklandığı söylenebilir. Keklerin kabuk rengi; hamurun su içeriği, $\mathrm{pH}$, indirgen şeker ve aminoasit miktarı, pişirme sıcaklığı, hava hızı, bağıl nemi gibi birçok etmenden etkilenmektedir (Olcay, 2019). Kek kabuklarının renk değerleri arasındaki farklar bu etmenlerdeki değişimler ile açıklanabilir. Siyah havuç unu içeren pandispanyaların kalite ve antioksidan özelliklerinin araştırıldığı bir çalışmada, havuç unu oranının artışına bağlı olarak keklerin hem kabuk hem de iç $L^{*}$ ve $b^{*}$ renk değerlerinin arttığı, kabuk $a^{*}$ renk değerlerinin düştüğü ancak iç $a^{*}$ renk değerlerinin arttığı rapor edilmiştir (Song ve ark., 2016). Ayrıca çalışmamızda elde edilen renk sonuçları diğer araştırmacılar tarafından bildirilen sonuçlarla da benzer bulunmuştur (Ataman ve Gül, 2020; Baltacıoğlu ve ark., 2020; Grasso ve ark., 2019; Aktaş ve Levent, 2018; GuadarramaLezama ve ark., 2016). 
Çizelge 5. Kek örneklerinin kabuk ve iç renk özellikleri"

Table 5. Crust and crumb color properties of cake samples"

\begin{tabular}{|c|c|c|c|c|c|c|}
\hline \multirow{2}{*}{$\begin{array}{l}\text { Mısır unu } \\
\text { ilave oranı } \\
\text { (\% w/w) } \\
\text { Corn flour } \\
\text { addition } \\
\text { ratio (\% } \\
w / w) \\
\end{array}$} & \multicolumn{3}{|c|}{$\begin{array}{l}\text { Kabuk rengi } \\
\text { Crust color }\end{array}$} & \multicolumn{3}{|c|}{$\begin{array}{c}\text { İç renk } \\
\text { Crumb color }\end{array}$} \\
\hline & $\mathrm{L}^{*}$ & $a^{*}$ & $b^{*}$ & $L^{*}$ & $a^{*}$ & $b^{*}$ \\
\hline 0 & $55.61 \pm 0.22^{\mathrm{e}}$ & $23.38 \pm 0.38^{a}$ & $32.79 \pm 0.26^{f}$ & $71.30 \pm 0.17^{f}$ & $0.38 \pm 0.01^{c}$ & $29.49 \pm 0.06^{e}$ \\
\hline 10 & $57.38 \pm 0.35^{d}$ & $21.48 \pm 0.24^{b}$ & $33.28 \pm 0.16^{\mathrm{e}}$ & $74.69 \pm 0.16^{e}$ & $0.45 \pm 0.04^{c}$ & $33.14 \pm 0.15^{d}$ \\
\hline 20 & $60.84 \pm 0.45^{c}$ & $20.68 \pm 0.27^{b}$ & $34.62 \pm 0.24^{d}$ & $76.44 \pm 0.08^{d}$ & $0.58 \pm 0.02^{b}$ & $34.28 \pm 0.25^{d}$ \\
\hline 30 & $63.78 \pm 0.23^{b}$ & $18.45 \pm 0.37^{c}$ & $36.63 \pm 0.11^{c}$ & $79.83 \pm 0.23^{c}$ & $0.63 \pm 0.03^{\mathrm{ab}}$ & $36.30 \pm 0.11^{c}$ \\
\hline 40 & $64.37 \pm 0.24^{b}$ & $17.10 \pm 0.13^{d}$ & $37.61 \pm 0.10^{b}$ & $82.00 \pm 0.10^{b}$ & $0.68 \pm 0.01^{a b}$ & $39.65 \pm 0.45^{b}$ \\
\hline 50 & $65.50 \pm 0.36^{a}$ & $13.29 \pm 0.28^{e}$ & $39.24 \pm 0.17^{a}$ & $83.38 \pm 0.20^{\mathrm{a}}$ & $0.75 \pm 0.03^{a}$ & $44.25 \pm 0.42^{a}$ \\
\hline
\end{tabular}

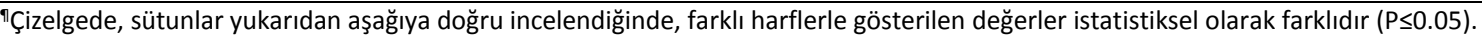

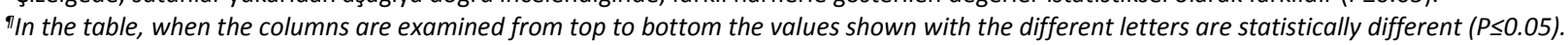

\section{Tekstür özellikleri}

Kek örneklerine uygulanan tekstür analizinde elastikiyet, keke uygulanan kuvvet ortadan kaldırıldıktan sonra kekin kuvvet uygulanmadan önceki haline dönme hızı; adesif yapışkanlık, kek ile kekin temas ettiği yüzey arasındaki çekim kuvvetini yenebilmesi için ortaya konulan iş olarak tanımlanmaktadır. Sertlik, kekin sıkıştırılması sırasında ölçülen maksimum kuvvet; çiğnenebilirlik ise kekin yutulmaya hazır hale gelene kadar ağızda parçalanması için gerekli iş olarak tanımlanmaktadır (ípek ve Dizlek, 2018). Kek örneklerinin tekstür analizi sonuçlarına ilişkin değerler Çizelge 6'da verilmiştir.

Çizelge 6. Kek örneklerinin tekstürel özellikleriף

Table 6. Textural properties of cake samples"

Özellikler

Properties

\begin{tabular}{cccc} 
& \multicolumn{3}{c}{ Corn flour ratio $(\% w / w)$} \\
& 10 & 20 & 30 \\
& \multicolumn{3}{c}{ 1. gün } \\
& 1st day \\
\hline
\end{tabular}

\section{Sertlik (N)}

Hardness (N)

Esneklik

Springiness

Çiğnenebilirlik

Chewiness

Yapışkanlık

Adhesiveness

iç yapışkanlık

Cohesiveness

Sertlik (N)

Hardness (N)

Esneklik

Springiness

Çiğnenebilirlik

Chewiness

Yapışkanlık

Adhesiveness

İç yapışkanlık

Cohesiveness

\begin{tabular}{ll}
\hline $8.68 \pm 1.56^{c}$ & $7.00 \pm 0.38^{\mathrm{c}}$ \\
$0.92 \pm 0.00^{\mathrm{a}}$ & $0.92 \pm 0.00^{\mathrm{a}}$ \\
$6.25 \pm 0.60^{\mathrm{b}}$ & $3.86 \pm 0.81^{\mathrm{c}}$ \\
$0.12 \pm 0.01^{\mathrm{c}}$ & $0.27 \pm 0.03^{\mathrm{bc}}$ \\
$0.73 \pm 0.03^{\mathrm{a}}$ & $0.71 \pm 0.02^{\mathrm{ab}}$ \\
\hline
\end{tabular}

$8.42 \pm 0.68^{c}$

$9.47 \pm 0.42^{b c}$

$12.39 \pm 0.56^{\mathrm{ab}}$

$14.78 \pm 0.63^{a}$

$0.91 \pm 0.00^{a}$

$0.89 \pm 0.00^{b}$

$0.88 \pm 0.01^{b}$

$0.86 \pm 0.00^{c}$

$5.52 \pm 0.48^{b c}$

$6.00 \pm 0.08^{b c}$

$6.72 \pm 0.48^{a b}$

$8.73 \pm 0.30^{a}$

$0.42 \pm 0.06^{\mathrm{ab}}$

$0.46 \pm 0.03^{a}$

$0.50 \pm 0.01^{a}$

$0.57 \pm 0.04^{\mathrm{a}}$

2. gün

2nd day

\begin{tabular}{llllll}
\hline $10.18 \pm 0.31^{\mathrm{c}}$ & $8.84 \pm 0.03^{\mathrm{d}}$ & $9.43 \pm 0.09^{\mathrm{cd}}$ & $10.35 \pm 0.32^{\mathrm{c}}$ & $13.65 \pm 0.28^{\mathrm{b}}$ & $17.90 \pm 0.03^{\mathrm{a}}$ \\
$0.90 \pm 0.00^{\mathrm{ab}}$ & $0.91 \pm 0.01^{\mathrm{a}}$ & $0.89 \pm 0.01^{\mathrm{abc}}$ & $0.88 \pm 0.01^{\mathrm{bc}}$ & $0.87 \pm 0.01^{\mathrm{cd}}$ & $0.85 \pm 0.01^{\mathrm{d}}$ \\
$6.93 \pm 0.08^{\mathrm{b}}$ & $4.24 \pm 0.47^{\mathrm{c}}$ & $6.18 \pm 0.70^{\mathrm{b}}$ & $6.75 \pm 0.55^{\mathrm{b}}$ & $7.64 \pm 1.00^{\mathrm{b}}$ & $9.56 \pm 0.45^{\mathrm{a}}$ \\
$0.49 \pm 0.02^{\mathrm{c}}$ & $0.68 \pm 0.09^{\mathrm{bc}}$ & $0.75 \pm 0.03^{\mathrm{ab}}$ & $0.85 \pm 0.04^{\mathrm{ab}}$ & $0.89 \pm 0.04^{\mathrm{a}}$ & $0.94 \pm 0.04^{\mathrm{a}}$ \\
$0.70 \pm 0.03^{\mathrm{a}}$ & $0.69 \pm 0.01^{\mathrm{a}}$ & $0.65 \pm 0.01^{\mathrm{ab}}$ & $0.62 \pm 0.01^{\mathrm{abc}}$ & $0.57 \pm 0.02^{\mathrm{bc}}$ & $0.54 \pm 0.02^{\mathrm{c}}$
\end{tabular}

"Çizelgede, aynı satırda farklı harfle gösterilen değerler arasındaki farklar 0.05 güven sınırına göre önemlidir.

"In the table, differences between values shown with different letters in the same line are significant compared to the 0.05 confidence level. 
Hamur formülüne mısır unu ilavesi keklerin sertliğini artırmıştır. Mısır unu ilaveli keklerin küçük hacimli olması bu azalmaya neden olmuş olabilir. Çünkü küçük hacim daha sıkı (yoğun) bir yapı oluşturduğundan sıkıştırmaya karşı daha fazla direnç göstermeye neden olmaktadır. En düşük sertlik değerinin kontrol örneğinde gözlendiği, mısır unu oranının artışı ile doğru orantılı olarak keklerin sertlik değerinin önemli ölçüde $(P \leq 0.05)$ arttığı saptanmıştır. Ayrıca kek örneklerinin sertlik değerleri depolama süresi ile artmıştır. Sertlik değerleriyle de uyumlu olarak mısır unu ile üretilen keklerin yutulmaya hazır hale gelene kadar ağızda parçalanmaları için gerekli iş miktarının (çiğnenebilirlik), bileşiminde mısır unu ihtiva etmeyen kontrol örneğinden daha fazla olduğu görülmüştür. Keklerin çiğneme değerlerinde ilk güne göre 2. gün artış olmuştur. Çiğneme değerinde en yüksek artış \% 50 mısır unu içeren örnekte saptanmıştır (Çizelge 6). Patates ununun kek formülasyonuna dâhil edildiği bir çalışmada çiğneme için benzer bir sonuç tespit edilmiştir (Gerçekaslan ve Boz, 2020).

Çizelge 6 incelendiğinde, mısır unu ilave edilerek üretilmiş keklerin kontrol kekine göre daha az esnek oldukları görülmektedir. Mısır unu ilaveli kek örneklerinin ilk gündeki esneklik değerleri ile 2. gün değerleri istatistiksel olarak birbirinden farklı bulunmuştur $(P \leq 0.05)$. Mısır unu ilave oranının artışına bağlı olarak hem 1. günde hem de 2. günde keklerin esneklik değerlerinde önemli bir düşüş olduğu görülmüştür. İkinci günde değerlerin, birinci güne göre düştüğü de tespit edilmiştir. Mısır unu kullanımının sertlik artırıcı etkisinden dolayı esneklik değerini düşürdüğü düşünülmektedir.

İç yapışkanlık değerinin ürünün nem seviyesi ile yakından ilişkili olduğu ve depolama sırasında nem kaybına bağlı olarak azaldığı bildirilmiştir (Yalçın ve Şeker, 2016). Farklı oranlarda mısır unu kullanılmasının keklerin iç yapışkanlık (bağlılık) değerleri üzerindeki etkisi önemli $(P \leq 0.05)$ bulunmuş olup, mısır unu katkı oranı arttıkça keklerin iç yapışkanlık değerlerinin düştüğü yani daha az yapışkan oldukları belirlenmiştir. Bu durumun buğday unu yerine ikame edilen mısır ununun kek içyapısını bozmasına bağlı olarak meydana geldiği düşünülmektedir. Gerçekaslan ve Boz (2020), patates ununun kek üretiminde kullanımının kek kalite parametrelerine etkisini araştırdıkları çalışmalarında patates unu ilave oranın artışına bağlı olarak keklerin sertlik, esneklik ve çiğnenebilirlik değerlerinde artış, iç yapışkanlık değerlerinde düşüş olduğunu saptamışlardır. Çalışmamızda tekstürel özelliklere ilişkin saptanan sonuçlar, diğer bazı çalışmalarda (Marchetti, 2018; Guadarrama-Lezama ve ark., 2016; Kim ve Cho, 2010; Chung ve Kim, 2009) saptanan sonuçlarla benzerlik göstermiştir.

\section{Duyusal özellikler}

Mısır unu ilaveli kek örneklerinin duyusal özelliklerine verilen puanlara ilişkin ortalama değerler Çizelge 7'de verilmiştir. Mısır unu ilavesi örneklerin tüm duyusal özelliklerinde önemli değişikliklere $(P \leq 0.05)$ neden olmuştur. Çizelge 7 incelendiğinde keklerin panelistlerden aldıkları ortalama kabuk renk değerleri 3.50 ile 3.85 arasında değişmiştir. En yüksek kabuk rengi puanı \%40 mısır unu ilaveli kek örneğine verilmiştir. Mısır unu ilaveli keklerin iç renk değerlerinin 3.50 ile 4.55 arasında değiştiği ve en yüksek puanı \%20 mısır unu ilaveli kek örneğinin aldığı görülmüştür.

Keklerin gözenek yapısı için aldıkları ortalama puanlar 3.10 ile 3.65 arasında değişmiştir. Kek yumuşaklığı puanlarına bakıldığında ise en yüksek puan (4.40) \%10 mısır unu ilaveli kek örneğinde görülmektedir. Tat-aroma özelliği ile ilgili olarak en yüksek puanı 4.05 değeri ile $\% 40$ mısır unu ilaveli örnek almıştır. Diğer mısır unu ilaveli kekler tat-aroma açısından kendi aralarında artan azalan değerler alırken en düşük puanı (3.20) \%10 mısır unu ilaveli kek örneği almıştır. Duyusal analizle belirlenen ağız hissi bakımından \%40 mısır unu ilaveli örnek en yüksek puanı (3.95) alırken, \%20 mısır unu ilaveli örnek ise en düşük puanı (3.15) almıştır.

Keklere genel kabul edilebilirlik açısından verilen puanlar 2.90 ile 4.05 değerleri arasında değişmiştir. Genel kabul edilebilirlik bakımından \%40 mısır unu ilaveli kek örneği en fazla beğeni alırken, en düşük beğeniyi kontrol örneği almıştır. 
Mısır unu ilaveli keklerin renk, tat-aroma ve ağız hissi özellikleri açısından yüksek puan alması aynı zamanda keklerin genel kabul edilebilirliğini de olumlu etkilemiştir. Bu da mısır unu ilaveli keklerin rahatlıkla tüketilebileceğini yani mısır ununun kek formülasyonlarında kullanılabileceğini göstermiştir.

Çizelge 7. Kek örneklerinin duyusal özellikleri"

Table 7. Sensory properties of cake samples"

Özellikler

Properties

Kabuk rengi

Crust color

İç renk

Crumb color

Gözenek yapısı

Pore structure

Kek yumuşaklığı

Cake softness

Tat-aroma

Taste-aroma

Ağız hissi

Mouthfeel

Genel kabuledilebilirlik Overall acceptability

\begin{tabular}{cccccc}
\multicolumn{5}{c}{$\begin{array}{c}\text { Misır unu oranı }(\% \mathrm{w} / \mathrm{w}) \\
\text { Corn flour ratio }(\% \mathrm{w} / \mathrm{w})\end{array}$} \\
\hline 0 & 10 & 20 & 30 & 40 & 50 \\
\hline $3.75 \pm 0.07^{\mathrm{ab}}$ & $3.65 \pm 0.07^{\mathrm{ab}}$ & $3.65 \pm 0.07^{\mathrm{ab}}$ & $3.50 \pm 0.00^{\mathrm{b}}$ & $3.85 \pm 0.07^{\mathrm{a}}$ & $3.75 \pm 0.07^{\mathrm{ab}}$ \\
$3.60 \pm 0.14^{\mathrm{bc}}$ & $4.10 \pm 0.14^{\mathrm{ab}}$ & $4.55 \pm 0.07^{\mathrm{a}}$ & $4.10 \pm 0.14^{\mathrm{ab}}$ & $3.70 \pm 0.07^{\mathrm{bc}}$ & $3.50 \pm 0.07^{\mathrm{c}}$ \\
$3.50 \pm 0.00^{\mathrm{a}}$ & $3.65 \pm 0.21^{\mathrm{a}}$ & $3.65 \pm 0.07^{\mathrm{a}}$ & $3.45 \pm 0.07^{\mathrm{ab}}$ & $3.10 \pm 0.00^{\mathrm{b}}$ & $3.30 \pm 0.14^{\mathrm{ab}}$ \\
$2.80 \pm 0.07^{\mathrm{d}}$ & $4.40 \pm 0.14^{\mathrm{a}}$ & $3.65 \pm 0.07^{\mathrm{b}}$ & $3.30 \pm 0.00^{\mathrm{bc}}$ & $2.95 \pm 0.07^{\mathrm{cd}}$ & $2.70 \pm 0.07^{\mathrm{d}}$ \\
$3.25 \pm 0.07^{\mathrm{c}}$ & $3.20 \pm 0.14^{\mathrm{c}}$ & $3.30 \pm 0.00^{\mathrm{c}}$ & $3.70 \pm 0.00^{\mathrm{b}}$ & $4.05 \pm 0.07^{\mathrm{a}}$ & $3.90 \pm 0.07^{\mathrm{ab}}$ \\
$3.50 \pm 0.00^{\mathrm{bc}}$ & $3.25 \pm 0.07^{\mathrm{cd}}$ & $3.15 \pm 0.07^{\mathrm{d}}$ & $3.70 \pm 0.14^{\mathrm{ab}}$ & $3.95 \pm 0.07^{\mathrm{a}}$ & $3.75 \pm 0.07^{\mathrm{ab}}$ \\
$2.90 \pm 0.14^{\mathrm{d}}$ & $3.10 \pm 0.14^{\mathrm{cd}}$ & $3.55 \pm 0.07^{\mathrm{bc}}$ & $3.95 \pm 0.07^{\mathrm{ab}}$ & $4.05 \pm 0.07^{\mathrm{a}}$ & $3.80 \pm 0.14^{\mathrm{ab}}$
\end{tabular}

"Çizelgede, aynı satırda farklı harfle gösterilen değerler arasındaki farklar 0.05 güven sınıına göre önemlidir.

$\pi / n$ the table, differences between values shown with different letters in the same line are significant compared to the 0.05 confidence level.

\section{Sonuçlar}

$\mathrm{Bu}$ çalışmada, mısır unu ilavesinin kek kalitesine etkisi araştırılmıştır. Kek formülasyonuna mısır unu eklenmesi; kül, yă̆, besinsel lif, toplam fenolik madde ve antioksidan içeriği bakımından örneklerin besin değerini (fonksiyonel özelliğini) artırmıştır. Mısır ununun kendine has rengi keklerin daha parlak ve daha sarı renkte görünmesine neden olmuştur. Kek örneklerinin tekstürel parametre değerlerinde mısır unu ilavesine bağlı olarak önemli değişimler saptanmıştır. Kontrol örneğine göre daha sert, daha sıkı ve çiğnenebilirliği zor kekler elde edilmiştir. Farklı oranlarda mısır unu kullanılarak üretilen pandispanya kek örneklerinin simetri indeks değerleri kontrol örneğinden düşük ama pozitif (+) bulunmuştur. Buna göre kek örneklerinin çökük bir yapıda olmadıkları ancak kontrole göre daha düşük hacimli oldukları görülmüştür. Mısır unu ilavesi örneklerin tüm duyusal özellik puanlarında kek yumuşaklığı hariç herhangi bir olumsuz değişikliğe neden olmamış ve kekler genel olarak beğenilmiştir. Sonuç olarak, mısır ununun kek formülasyonunda kullanımının özellikle besinsel özellikleri (toplam besinsel lif, toplam fenolik madde ve antioksidan aktivite) arttırdığı ve mısır ununun kek zenginleştirilmesinde fonksiyonel bir katkı olarak kullanılabileceği sonucuna varılmıştır.

Çıkar Çatışması Beyanı: Makale yazarları aralarında herhangi bir çıkar çatışması olmadığını beyan ederler.

Yazar Katkısı: Mehmet KÖTEN araştırmayı tasarlayarak makalenin kavramsallaştırma, metodoloji, biçimsel analiz, yazma-orijinal taslak, yazma-inceleme, düzenleme ve görselleştirmesine katkı sunmuştur. Ahmet Sabri ÜNSAL makaleye metodoloji, biçimsel analiz, istatistiksel analiz ve görselleştirme olarak katkı sağlamıştır. Yazarlar makalenin son halini okumuş ve onaylamıştır.

\section{Kaynaklar}

AACC, (2010). Approved Methods of the American Association of Cereal Chemists. Approved Methods of Analysis 11th Edition, Cereals \& Grains Association: St. Paul, MN, U.S.A.

Algül, I. (2012). Mısır ununda aflatoksin, oflatoksin A ve ağır 
metal içeriklerinin belirlenmesi ve kemometrik olarak değerlendirilmesi. (Yayımlanmamış yüksek lisans tezi). Balıkesir Üniversitesi Fen Bilimleri Enstitüsü, Balıkesir.

Aktaş, K. \& Levent, H. (2018). The effects of Chia (Salvia hispanica L.) and Quinoa flours on the qualıty of rice flour and starch based-cakes. GIda, 43(4), 644-654. doi:10.15237/gida.GD18032

Argun, M. Ş. (2016). Ülkemizde yetiştirilen bazı mısır çeşitlerine uygulanan alkali pişirme işleminin mısır unlarının karakteristik özellikleri üzerine etkilerinin araştırılması. (Yayımlanmamış doktora tezi). Van Yüzüncü Yıl Üniversitesi Fen Bilimleri Enstitüsü, Van.

Ataman, Ç. \& Gül, H. (2020). Leblebi üretiminde yan ürün olarak açığa çıkan kırık leblebi ununun mufin kalitesi üzerine etkisi. Black Sea Journal of Agriculture, 3(4), 308-316.

Baltacıoğlu, C., Temizsoy, B., Kanbur, M., Doğan, M. \& ibili, S. (2020). Hindiba (Cichorium intybus L.) kökü ekstraktı ve trabzon hurması (Diospyros kaki L.) tozunun kek üretiminde kullanılması ve kalite parametreleri üzerine etkisinin incelenmesi. Niğde Ömer Halisdemir Üniversitesi Mühendislik Bilimleri Dergisi, 9(1), 297-307. doi:10.28948/ngumuh.623417

Chung, Y.S. \& Kim, D.J. (2009). Quality characteristics of sponge cake with pakchoi (Brassica Campestris L. Ssp. Chinensis Jusl.) powder. Journal of the Korean Society of Food Science and Nutrition, 38(7), 914-919. doi:10.3746/jkfn.2009.38.7.914

De la Hera, E., Ruiz-París, E., Oliete, B. \& Gómez, M. (2012). Studies of the quality of cakes made with wheatlentil composite flours. LWT-Food Science and Technology, 49(1), 48-54. doi:10.1016/j.lwt.2012.05.009

Dhen, N., Román, L., Ben Rejeb, I., Martínez, M.M., Garogouri, M. \& Gómez, M. (2016). Particle size distribution of soy flour affecting the quality of enriched gluten-free cakes. LWT-Food Science and Technology, 66, 179-185. doi:10.1016/j.lwt.2015.10.032

Dizlek, H. (2015). Effects of amount of batter in baking cup on muffin quality. International Journal of Food Engineering, 11(5), 629-640. doi:10.1515/ijfe-20150066

Dizlek, H. \& Özer, M.S. (2017). The effects of various ratios of sunflower oil and surfactant on household type cake quality. quality. Journal of Food Measurement and Characterization, 12(1), 173-181. doi:10.1007/s11694-017-9628-9

Dizlek, H. \& Altan, A. (2015). Determination of sponge cake volume with a mathematical method. Quality Assurance and Safety of Crops \& Foods, 7(4), 551557. doi:10.3920/qas2014.0463

Drabińska, N., Ciska, E., Szmatowicz, B. \& Krupa-Kozak, U. (2018). Broccoli by-products improve the nutraceutical potential of gluten-free mini sponge cakes. Food Chemistry, 267, 170-177. doi:10.1016/j.foodchem.2017.08.119

Emmanuel, K. \& Sackle, A. (2013). Nutritional and sensory analysis of millet based sponge cake. International Journal of Nutrition and Food Science, 2(6), 287-293. doi:10.11648/j.ijnfs.20130206.14

Gerçekaslan, K. E. \& Boz, H. (2020). Effect of potato flour substitute to wheat flour on the physıcal quality propertıes of cupcake. Gıda, 45(2), 390-396. doi:10.15237/gida.GD20018

Gomez, M., Oliete, B., Rosell, C.M., Pando, V. \& Fernandez, E. (2008). Studies on cake quality made of wheatchickpea flour blends. LWT-Food Science and Technology, 41(9), 1701-1709. doi:10.1016/j.lwt.2007.11.024

Grasso, S., Lui, S. \& Methven, L. (2019). Quality of muffins enriched with upcycled defatted sunflower seed flour. LWT-Food Science and Technology, 119, 108893. doi:10.1016/j.Iwt.2019.108893

Guadarrama-Lezama, A.Y., Carrillo-Navas, H., Pérez-Alonso, C., Vernon-Carter, E.J. \& Alvarez-Ramirez, J. (2016). Thermal and rheological properties of sponge cake batters and texture and microstructural characteristics of sponge cake made with native corn starch in partial or total replacement of wheat flour. LWT-Food Science and Technology, 70, 46-54. doi:10.1016/j.Iwt.2016.02.031

Haug, W. \& Lantzsch, H. J. (1983). Sensitive method for the rapid determination of phytate in cereals and cereal products. Journal of the Science of Food and Agriculture, 34, 1423-1426. https://doi.org/10.1002/jsfa.2740341217

inceer, N.E. (2011). Mısır bulgurunun bazı besinsel ve teknolojik özellikleri üzerine farklı olum devrelerinin ve bazı mısır varyetelerinin etkisi. (Yayımlanmamış yüksek lisans tezi). Selçuk Üniversitesi Fen Bilimleri Enstitüsü, Konya.

İpek, T. \& Dizlek, H. (2018). Farklı form ve oranlarda yerfıstığı ürünleri kullanılmasının top kek kalitesine etkisi. Gida, 43(4), 591-604. doi:10.15237/gida.GD18027

Kaur, A., Kaur, R. \& Bhise, S. (2020). Baking and sensory quality of germinated and ungerminated flaxseed muffins prepared from wheat flour and wheat atta. Journal of the Saudi Society of Agricultural Sciences, 19(1), 109-120. doi:10.1016/j.jssas.2018.07.002

Kaur, R. \& Kaur, M. (2018). Microstructural, physicochemical, antioxidant, textural and quality characteristics of wheat muffins as influenced by partial replacement with ground flaxseed. LWT-Food Science and Technology, 91, 278-285. doi:10.1016/j.lwt.2018.01.059

Kılınççeker, O. \& Hepsağ, F. (2010). Kaplama malzemesi olarak mısır unlarının bazı kalite özelliklerinin belirlenmesi. Gıda Teknolojileri Elektronik Dergisi, 5(2), 20-27.

Kim, C.H. \& Cho, K.R. (2010). Quality characteristics of sponge cakes made with different quantities of broccoli powder. Korean Journal of Food Science and Technology, 42(2), 459-467.

Lee, S.C., Prosky, L. and Devries, J.W. (1992). Determination of total, soluble, and insoluble dietary fiber in foodsenzymatic-gravimetric method, MES-TRIS buffer: Collaborative study. Journal - Association of Official Analytical Chemists, 75, 395-416. ISSN : 1060-3271

Majoobi, M., Poor, Z.V., Jamalian, J. \& Farahnaky, A. (2016). Improvement of the quality of gluten-free sponge cake using different levels and particle sizes of carrot pomace powder. International Journal of Food Science and Technology, 51, 1369-1377. 
doi:10.1111/ijfs.13104

Marchetti, L., Califano, A.N. \& Andrés, S.C. (2018). Partial replacement of wheat flour by pecan nut expeller meal on bakery products. Effect on muffins quality. LWT- Food Science and Technology, 95, 85-91. doi:10.1016/j.Iwt.2018.04.050

Olcay, N. (2019). Farklı teknikler ile kurutulmuş kamkat meyvesinin, bisküvi ve kek üretiminde kullanım imkânları. (Yayımlanmamış yüksek lisans tezi). Necmettin Erbakan Üniversitesi Fen Bilimleri Enstitüsü, Konya.

Prosky, L., Asp, N.G., Schweizer, T.F., Devries, J.W. \& Furda, I. (1992). Determination of insoluble and soluble dietary fiber in foods and food products, Collaborative study. Journal - Association of Official Analytical Chemists, 75, 360-367.

Prosky, L., Asp, N.G., Schweizer, T.F., Devries, J.W. \& Furda, I. (1988). Determination of insoluble, soluble and total dietary fiber in foods and food products, interlaboratory study. Journal - Association of Official Analytical Chemists, 71, 1017-1023.

Song, K.Y, O, H., Zhang, Y. \& Kim, Y.S. (2016). Quality characteristics and antioxidant properties of sponge cakes containing black carrot (Daucus carota ssp. sativus var. atrorubens Alef) flour. Progress in Nutrition, 18(2), 176-183.

Volpini-Rapina, L.F., Sokei, F.R. \& Conti-Silva, A.C. (2012). Sensory profile and preference mapping of orange cakes with addition of prebiotics inulin and oligofructose. LWT-Food Science and Technology, 48(1), 37-42. doi:10.1016/j.Iwt.2012.03.008

Yalçın, M.Y. \& Şeker, M. (2016). Effect of salt and moisture content reduction on physical and microbiological properties of salted, pressed and freeze dried turkey meat. LWT-Food Science and Technology, 68, 153159. doi:10.1016/j.Iwt.2015.12.032 